\title{
ISLAM NUSANTARA MENURUT GUS DUR: KAJIAN PRIBUMISASI
}

\section{ISLAM}

\section{Fathoni Ahmad}

Dosen STAINU Jakarta, Redaktur NU Online, Peneliti Aliansi Kebangsaan

\begin{abstract}
Islam Nusantara is a manifestation of Islam with local culture. Gus Dur review of the history of the archipelago is done through two approaches, description and prescription. Approach description, Gus Dur portrayal of Islam in the archipelago objectively. While the approach of prescriptions, Gus Dur reading of Islam in the archipelago using certain perspectives in the view of Islam in the archipelago. Presrikptif of this approach, born of Islamic terms archipelago.

Islam Nusantara basing itself on the discussion of religion, tradition, and culture, the culture of Islam in the archipelago. Gus Dur theory that suggests about pergualatan religion and culture is indigenization of Islam. Therefore, this study examines the Islamic epistemology country through the implementation of indigenization of Islam. The approach used to assess the earthing Islam in the archipelago by Gus Dur ie indigenization approach.

Through theoryand approach pribumisasi Islamindigenization, the studyfoundelements that helped shape the unique pattern of Islam Nusantara. Gus Dur through texts reveal patterns of Islamization wave archipelago that is the Sufi approach, syariatisasi Sufism and Sufi Jurisprudence. Gus Dur also expanding their own Islam Nusantara into what he described as an embodiment of cultural Islam. This embodiment is called cultural, because he shaped the cultural acculturation between Islam and cultural heritage.
\end{abstract}

Keywords: Indigenization of Islam, Islam Nusantara, Gus Dur, Tradition, Culture

\begin{abstract}
Abstrak
Islam Nusantara merupakan perwujudan Islam melalui budaya lokal. Ulasan Gus Dur tentang sejarah di Nusantara dilakukan melalui dua pendekatan, deskripsi dan preskripsi. Pendekatan deskripsi, Gus Dur hanya menggambarkan Islam di Nusantara secara objektif. Sedangkan pendekatan preskripsi, Gus Dur membaca Islam di Nusantara dengan menggunakan perspeksi tertentu dalam melihat Islam di Nusantara. Dari pendekatan presrikptif ini, lahirlah terma Islam Nusantara.

Islam Nusantara mendasarkan diri pada pembahasan agama, tradisi, dan budaya, yakni budaya Islam di Nusantara. Teori Gus Dur yang mengemukakan tentang pergualatan agama dan budaya adalah pribumisasi Islam. Sebab itu, penelitian ini mengkaji tentang epistemologi Islam Nusantara melalui penerapan pribumisasi Islam. Pendekatan yang digunakan untuk mengkaji pembumian Islam di Nusantara menurut Gus Dur yaitu pendekatan Indigenisasi.
\end{abstract}

Vol. 4 No. 1 April $2018 \quad$ Halaman $21-40$ 
Melalui teori pribumisasi Islam dan pendekatan indigenisasi, penelitian ini menemukan unsur yang turut membentuk corak khas Islam Nusantara. Gus Dur lewat teks-teksnya mengungkapkan pola-pola gelombang Islamisasi Nusantara yaitu dengan pendekatan sufistik, syariatisasi tasawuf, dan fikih sufistik. Gus Dur juga melakukan perluasan corak Islam Nusantara menjadi apa yang ia sebut sebagai perwujudan kultural Islam. Perwujudan ini disebut kultural, sebab ia berbentuk budaya hasil akulturasi antara Islam dan budaya Nusantara.

pesantren ini juga memiliki peran yang besar di masyarakat, baik di wilayah dakwah Islam maupun dalam politik.

Kata Kunci: Pribumisasi Islam, Islam Nusantara, Gus Dur, Tradisi, Budaya

\section{PENDAHULUAN}

Konsep Gus Dur tentang pribumisasi Islam terkait dengan apa yang disebut Islam Nusantara, yakni perwujudan Islam melalui tardisi dan budaya lokal Nusantara. Kata 'melalui' di sini mempunyai arti, bahwa antara Islam dan tradisi lokal tidak mengalami reduksi. Dengan kata lain, Islam tetap pada karakternya, budaya juga tetap pada karakternya sehingga satu sama lain tidak bersifat dominatif.

Berbeda dengan kata 'ke dalam' yang mempunyai arti bahwa kedua entitas tersebut saling melebur (berasimilasi) sehingga hilang sama sekali. Terkait istilah Pribumisasi Islam, Gus Dur menjelaskan bahwa dirinya menggunakan istilah 'pribumisasi Islam', karena kesulitan mencari kata lain. 'Domestikasi Islam terasa berbau politik, yaitu penjinakan sikap dan pengebirian pendirian. Dengan konsep pribumisasinya ini, Gus Dur juga ingin menjelaskan, bahwa wilayah pribumisasi Islam bukan pada inti keimanan dan ibadah formal, namun perwujudan Islamnya, sehingga tetap Islam 100 persen tetapi tidak hilang karakter.

Gus Dur menggagas Pribumisasi Islam karena memahami dan melihat fenomena keislaman di Indonesia yang justru mereduksi budaya dan lokalitas oleh bangsanya sendiri dengan menonjolkan diri bersama simbol-simbol lokalitas Arab secara verbal maupun fisik. Tidak hanya itu, mereka bahkan menganggap bahwa Islam itu Arab. Sehingga menolak bentuk keislaman lokal yang sesungguhnya manisfestasi universalisme Islam. Artinya, sesungguhnya lokalitas diwarnai oleh Islam, bukan sebaliknya, Islam diwarnai oleh lokalitas. Sehingga pada titik ini, pribumisasi Islam menemukan urgensinya sebagai metode dalam membentuk Islam 
Nusantara.

Dengan tetap mengakomodasi budaya, seseorang tetap bisa menjadi muslim seratus persen dengan tetap menjalani tradisi dan budaya seperti nyadran, sedekah bumi, selametan, dan tradisi-tradisi lokal nusantara lain yang menjadi basis kultural kehidupan masyarakat nusantara. Gus Dur mengatakan,

Yang 'dipribumikan' adalah manifestasi kehidupan Islam belaka. Bukan ajaran yang menyangkut inti keimanan dan peribadatan formalnya. Tidak diperlukan 'Qur'an Batak' dan 'Hadis Jawa'. Islam tetap Islam, dimana saja berada. Namun tidak berarti semua harus disamakan 'bentuk luarnya' (Wahid, 1999: 108).

Manisfestasi kehidupan Islam melalui tradisi dan budaya lokal itulah konsep kenusantaraan Gus Dur dalam mewujudkan Islam yang khas nusantara. Tentu pemikiran Gus Dur ini tidak jauh dari pemahaman Islam para Wali Songo yang menggunakan tradisi dan budaya lokal sebagai instrumen penyebaran agama Islam saat itu.

Wali Songo, begitu pula Gus Dur, sangat menyadari bahwa agama tidak bisa tumbuh jika tidak ada media tanam. Seperti halnya tumbuhan tidak memiliki media tanam yaitu tanah. Oleh karena itu, pribumisasi Islam menurut Gus Dur dalam dapat dikatakan mengembangkan tradisi, budaya, maupun seni lokal untuk menginternalisasi nilai-nilai Islam ke dalam masyarakat nusantara. Sehingga nusantara dapat dijadikan sebagai media aktualisasi Islam.

\section{PRIBUMISASI ISLAM SEBAGAI METODOLOGI}

Secara historis, pribumisasi Islam adalah cara Gus Dur khususnya dan NU umumnya untuk menolak Arabisasi. Tapi ini juga bukan pikiran baru yang datang dari Gus Dur, karena sejak dulu para kiai pesantren sudah punya kecenderungan untuk menghadirkan jenis keislaman yang khas Indonesia, tanpa banyak dicampur unsur Arabisme. Jadi, pribumisasi Islam hanya stempelnya saja. Gus Dur berjasa menteorikan- nya. Gus Dur telah memberi nama terhadap jenis perjuangan yang dilakukan oleh para ulama Indonesia sejak Wali Songo sampai sekarang.

Sebagai metode untuk memahami Islam yang termanifestaskan melalui tradisi 
dan budaya lokal, pribumisasi Islam bukan tanpa tantangan. Kalangan arab dengan paham wahabi misalnya, yang hingga sekarang masih menilai bahwa paham Islam yang dicampuradukkan dengan budaya membuat Islam tidak lagi murni secara teologis. Padahal seperti yang sudah Gus Dur jelaskan di awal, pribumisasi Islam tidak menyentuh wilayah keimanan seseorang atau ibadahnya secara formal. Hal ini seperti yang telah dikatakan Gus Dur di atas.

Perlu dicatat bahwa Gus Dur, dalam konteks Islam Nusantara hanya berbicara tentang pribumisasi Islam yang merupakan proses dan mekanisme bagi terbentuknya kultur Islam Nusantara. Dengan demikian, dalam diskursus Islam Nusantara, Gus Dur hanya mewariskan metodologi bagi Islam Nusantara, dan tidak tentang Islam Nusantara itu sendiri. Namun demikian, pandangan tentang Islam Nusantara bisa didapatkan pada pandangan Gus Dur tentang sejarah kedatangan Islam di Nusantara, proses akulturasi antara Islam dan budaya Nusantara, hingga corak kultural dari keislaman pesantren, yang menurutnya menjadi produk akumulatif dari islamisasi di Nusantara.

Dalam kaitan ini, karena wilayah Islam Nusantara berada pada wilayah Islam dan budaya Nusantara, maka pribumisasi Islam menjadi metodologi bagi pembumian Islam ke dalam budaya tersebut. Hal ini terjadi karena pribumisasi Islam merupakan proses peleraian ketegangan antara Islam dan budaya. Islam merupakan agama hukum yang memuat jaringan aturan, sedangkan budaya merupakan kreasi manusia yang memuat proses perubahan. Antara aturan yang menuntut ketetapan, dengan kreasi yang meniscayakan perubahan; sering melahirkan kontradiksi dan akhirnya ketegangan antara agama dan kebudayaan.

Seperti yang berusaha penulis sampaikan, manifestasi Islam melalui tradisi dan budaya lokal bukan tanpa resistensi. Hal ini karena sifat Islam dan budaya yang cenderung tumpang tindih (overlapping) seperti yang dikemukakan oleh Gus Dur:

"Agama (Islam) dan budaya mempunyai independensimasing-masing,tetapi keduanya mempunyai wilayah tumpang tindih. Bisa dibandingkan dengan independensi antara filsafat dan ilmu pengetahuan. Orang tidak bisa berfilsafat tanap ilmu pengetahuan, tetapi tidak bisa dikatakan bahwa ilmu pengetahuan adalah filsafat. Di antara keduanya terjadi tumpang tindih dan sekaligus perbedaan-perbedaan" (Wahid, 2001: 117).

Vol. 4 No. 1 April $2018 \quad$ Halaman $21-40$ 
Oleh karena itu, pribumisasi Islam memuat beberapa pemahaman. Pertama, pribumisasi Islam adalah bagian dari sejarah Islam, baik di negeri Arab maupun di negeri lain, termasuk Indonesia. Kedua sejarah itu membentuk sungai besar yang terus mengalir dan kemudian dimasuki lagi oleh kali cadangan sehingga sungai itu semakin membesar. Bergabungnya kali baru, berarti masuknya air baru yang mengubah warna air yang telah ada. Bahkan pada tahap berikutnya, aliran sungai ini terkena 'limbah industri' yang sangat kotor. Maksud dari perumpamaan itu adalah bahwa proses pergulatan dengan kenyataan sejarah tidaklah mengubah Islam, melainkan hanya mengubah manifestasi dari kehidupan agama Islam.

Kedua, pribumisasi Islam bukanlah 'Jawanisasi' atau sinkretisme, sebab ia hanya proses mempertimbangkan kebutuhan lokal di dalam merumuskan hukumhukum agama, tanpa mengubah hukum itu sendiri. Ketiga, pribumisasi Islam bukan upaya meninggalkan norma demi budaya, tetapi agar norma-norma itu menampung kebutuhan-kebutuhan dari budaya dengan mempergunakan peluang yang disediakan oleh variasi pemahaman nash, dengan tetap memberikan peranan kepada ushul fiqh dan qaidah fiqh. Keempat, pribumisasi Islam merupakan pengembangan pemahaman nash agar berjalan lebih sistematik dengan cakupan yang lebih luas dan argumentasi yang lebih matang. Jika hal ini terjadi, maka Islam telah dipribumisasikan, yakni pemahaman terhadap nash dikaitkan dengan masalah-masalah di negeri kita" (Wahid, 2001: 119-124).

Di samping pemahaman yang bersifat positif yang menguraikan "apa itu" pribumisasi Islam, Gus Dur juga menyediakan "batasan negatif” tentang "apa yang tidak boleh terjadi" dalam pribumisasi Islam. Meliputi, pertama, tidak boleh terjadi pembauran Islam dengan budaya, sebab berbaur berarti hilangnya sifat-sifat asli. Islam harus tetap pada sifat Islamnya. Al-Qur'an harus tetap dalam bahasa Arab, terutama dalam shalat, sebab hal ini telah menjadi norma. Kedua, penyesuaian ajaran Islam dengan kenyataan hidup hanya diperkenankan sepanjang menyangkut sisi budaya. Dalam soal wali nikah misalnya, ayah angkat tetap bukan wali nikah untuk anak angkatnya. Ketentuan ini adalah norma agama, bukan kebiasaan.

Ketiga, karena adanya prinsip-prinsip yang keras dalam hukum Islam, maka adat tidak bisa mengubah nash melainkan hanya mengubah atau mengembangkan Vol. 4 No. 1 April 2018 Halaman $21-40$ 
aplikasinya saja dan memang aplikasi tersebut akan berubah dengan sendirinya. Misalnya, Nabi tidak pernah menetapkan beras sebagai benda zakat, melainkan gandum. Lalu ulama yang mendefinisikan gandum sebagai qutul balad, makanan pokok. Dan karena definisi itulah, gandum berubah menjadi beras untuk Indonesia (Wahid, 2001: 119-123).

Dari sini kita bisa memahami bahwa pribumisasi Islam digerakkan Gus Dur dalam dua maksud. Pertama, kontekstualisasi Islam. Di dalam maksud ini, terdapat dua pemahaman, yakni: 1) Akomodasi adat oleh fiqih (al-'adah muhakkamah). Contoh: akomodasi hukum waris Islam atas adat waris lokal seperti adat perpantangan (Banjarmasin) dan gono-gini (Yogyakarta-Solo). Akomodasi ini dilakukan melalui pemilahan harta warisan menjadi dua bagian. Bagian pertama dibagi menurut tradisi gono-gini, bagian separuhnya dibagi melalui waris Islam. 2) Pengembangan aplikasi nash. Contoh: Setelah lahir wacana emansipasi wanita (modern), dibutuhkan perubahan cara-pandang keadilan dari keadilan menurut suami, menjadi keadilan menurut istri dalam kasus poligami. Kasus ini merujuk pada AlQur'an Surat An-Nisa ayat 3 yang menjelaskan, “Dan jika kamu khawatir tidak akan maтри berlaku adil terhadap (hak-hak) perempuan yatim (bilamana kamu menikahinya), maka nikahilah perempuan (lain) yang kamu senangi: dua, tiga, atau empat. Tetapi jika kaти khawatir tidak akan maтрu berbuat adil, maka (nikahilah) seorang saja atau hamba sahaya perempuan yang kamu miliki. Yang demikian itu lebih dekat agar kamu tidak berbuat dzalim." Dengan adanya perubahan cara pandang atas keadilan, maka istri mendapat keadilan dengan cara tidak dipoligami, tanpa harus mengganti nash al-Qur'an itu sendiri.

Keempat, kulturalisasi Islam. Poin inilah yang melahirkan manifestasi (bentuk) Islam dalam kultur lokal. Contoh, atap Masjid Demak yang menggunakan arsitektur rumah ibadah Kapitayan, yakni atap "Meru". Dalam kerangka ini, dilakukanlah “islamisasi substansi” dengan tetap menjaga bentuk budaya lokal. Mengapa? Karena atap "Meru" yang dijadikan atap masjid, telah diislamkan melalui pemaknaan tiga sap dalam atap "Meru"; atap paling bawah menggambarkan tahapan iman, kemudian Islam dan akhirnya iman. Orang baru berada di tahapan paling bawah ketika ia hanya mengikrarkan iman secara lisan. Setelah melaksanakan syariah, baru ia menapaki tahap 
selanjutnya: Islam. Namun tahapan Islam-syariah ini bukan tahap tertinggi, sebab ia merupakan tahap-antara menuju ihsan: penyerahan diri secara total kepada Allah dengan pengamalan agama yang merujuk pada penyebaran rahmat bagi seluruh alam (Wahid, 2001: 118).

\section{RUMUSAN PEMIKIRAN GUS DUR}

Proses pribumisasi Islam dalam kerangka manifestasi Islam dalam bentuk budaya lokal ini telah menjadi mekanisme kultural bagi terbentuknya Islam Nusantara. Dalam perkembangannya, Gus Dur memiliki dua macam pemikiran tentang Islam Nusantara. Pertama, deskriptif. Model pemikiran ini bersifat menggambarkan fakta Islam di Nusantara beserta keragaman karakter kulturalnya. Dalam model ini Gus Dur bersifat bebas-nilai dan hanya ingin mendeskripsikan kemajemukan Islam di Nusantara.

Kedua, preskriptif. Dalam model pemikiran ini, Gus Dur sudah memiliki preskripsi tertentu dalam melihat apa yang terbaik dari Islam Nusantara. Preskripsi ini lahir dari pribumisasi Islam sebagai paradigma keislamannya. Oleh karena itu, Gus Dur telah menempatkan pribumisasi Islam yang merupakan mekanisme akulturasi Islam dan budaya Nusantara, sebagai paradigma keislaman yang menentukan idealitas keislaman di Nusantara dan di Indonesia. Oleh karenanya, paradigma pribumisasi Islam kemudian melahirkan corak ideal Islam Nusantara yang unik, karena memiliki sistem nilai dan pola budaya sendiri. Pada titik ini Gus Dur sudah tidak bebas- nilai lagi karena ia membasiskan diri pada paradigma Islam pribumi. Menurut Gus Dur:

"Hingga saat ini, dunia pengetahuan di negeri ini masih menerima pendapat
bahwa Islam dibawa kemari oleh para pedagang Arab. Akan tetapi, S.Q.
Fatimi dalam karyanya yang bertitel, Islam Comes to Malaysia (Singapura,
1963), secara halus menolak anggapan itu, dan membuktikan masuknya
Islam ke kawasan ini adalah karena usaha para dai (misionaris) mistik
Islam dari wilayah Bengal. Pendapat Fatimi ini lebih mendekati hakikat
penyebaran Islam setelah masuk ke kawasan ini, yaitu dengan
berkembangnya watak mistik yang sesuai (indigenous) dengan sikap di
kawasan ini semenjak zaman pra-Hindu”.

Di pihak lain, teori masuknya Islam kemari melalui pedagang Arab juga terpukul oleh hasil penelitian O. B. Wolters, umpamanya dalam Early Indonesian 
Commerce (London, 1966). Wolters membuktikan bahwa kelas pedagang yang menguasai teritorial niaga laut antara Sailan dan Tiongkok sejak abad ke-16 Masehi justru adalah saudagar-saudagar Melayu sendiri yang berpuncak pada kerajaan Sriwijaya dua abad kemudian. Dengan demikian, patahlah anggapan bahwa saudagar Arab datang kemari dan menyebarkan agama dengan cara perkawinan, sedangkan mereka ini juga baru pada abad ke-10 M.

Rekonstruksi kesejarahan yang dibuat van Leur, di mana dinasti pribumi mendatangkan para ahli agama dari India untuk memperkuat legitimasi klaim mereka atas takhta kerajaan di masa Hindu juga sesuai dengan kemungkinan para da'i mistik yang diundang kemari untuk memperkuat klaim dinasti pribumi yang sedang memberontak atau mengalami pemberontakan setelah mengendurnya kekuasaan Majapahit. Adapun keterangan as-Sairafi tentang adanya masyarakat Islam di kawasan ini pada abad ke-13 H, sama sekali bukanlah argumentasi untuk memperkuat klaim pedagang Arab sebagai pembawa Islam, bahkan mungkin sebaliknya, mereka datang setelah Islam tersebar di Kepulauan Nusantara” (Wahid, 2007: 12-13).

Dalam teks di atas, Gus Dur melakukan kritik atas pendekatan sejarah yang menempatkan para pedagang Arab sebagai pembawa Islam ke Nusantara. Kritik ini dilakukan mengingat corak keislaman Nusantara yang bersifat sufistik, yang menandakan peran para misionaris mistik, daripada sebatas kaum pedagang. Watak sufistik ini yang menjadi corak utama dari Islam pertama di Nusantara, yang akan mempengaruhi corak kultural dari Islam pribumi tersebut. Dalam teks lain, Gus Dur menguraikan:

"Islam came to Indonesia in a peaceful manner, through trade and mystical movements. Although it came very early from the Arabian peninsula, some say during the first century of Islam or the middle of the eight century A.D., Islam did not really make its presence felt in this region until the $13^{\text {th }}$ century A.D., when the first Islamic communities were established in the northern tip of Sumatera. Subsequently it spread to the west coast of Malacca, eastern coast of Kalimantan, southern of Sulawesi, the northern island of the Moluccas, and the northern coast of Java. But not until the fifteen century A.D. that strong Islamic kingdoms began to appear on the scenes. When the first European "explorers" reached the region, and then followed directly by merchant ships, they had to deal with indigenous 
Muslim rulers. This they did effectively, as witnessed by history" (Wahid, 1985: 1).

(Islam datang ke Indonesia dengan cara damai, melalui gerakan perdagangan dan mistik. Meskipun ia datang sangat awal dari jazirah Arab, beberapa mengatakan selama abad pertama Islam atau pertengahan abad ke-8 M, Islam tidak benar-benar menampakkan dirinya di wilayah ini hingga abad ke-13 M, ketika komunitas Islam pertama berdiri di ujung utara Sumatera. Selanjutnya ia menyebar ke pantai barat Malaka, pantai timur Kalimantan, Sulawesi Tenggara, pulau utara Melayu, dan pantai utara Jawa. Tetapi tidak sampai abad ke-15 M, sebuah kerajaan Islam besar mulai Nampak di wilayah tersebut. Ketika para "penjelajah" Eropa awal mencapai wilayah itu, dan diikuti secara langsung oleh kapal perdagangan, mereka telah bertemu dengan pemerintahan muslim pribumi. Hal ini terjadi secara efektif, sebagaimana disaksikan oleh sejarah).

Teks di atas juga menggambarkan paparan Gus Dur atas historisitas Islam di Nusantara. Hanya saja dalam teks ini, Gus Dur menambahkan peran para pedagang sebagai penyebar Islam, selain para mistikus yang telah dijelaskan di atas. Jadi, meskipun Gus Dur mengritik pendekatan kaum pedagang atas kehadiran Islam, namun ia tidak menafikan peran pedagang dalam Islamisasi Nusantara dengan titik tekan kepada peran utama kaum mistikus.

Gus Dur juga memaparkan tahun datangnya Islam. Ia bahkan mengutip pendapat yang menyatakan kehadiran Islam di Nusantara sejak abad pertama Hijriyah atau abad ke-8 Masehi. Meskipun perkiraan kehadiran Islam di awal abad tersebut, namun gelombang islamisasi baru benar-benar terjadi pada abad ke-13 M dengan ditandai oleh terbentuknya komunitas Islam di ujung utara Sumatera. Secara berturutturut, Islam telah menyebar di pantai barat Malaka, pantai timur Kalimantan, bagian utara Sulawesi, pulau utara Maluku, dan pantai utara Jawa. Segenap gelombang islamisasi ini terjadi dan memuncak pada pembentukan kerajaan- kerajaan Islam, sejak di Pasai, Perlak, Goa, Kerajaan Aceh, Demak dan Mataram (Wahid, 1981: 5). Hal ini menunjukkkan bahwa keragaman wilayah yang diislamkan telah melahirkan keragaman corak keislaman yang membekaskan corak budaya Islam itu sendiri.

Dari paparan di atas, beberapa kesimpulan bisa ditarik. Pertama, Gus Dur melihat peran utama dai mistik (sufi) dalam islamisasi di Nusantara, meskipun ia tidak mengesampingkan peran pedagang. Keutamaan peran para sufi ini yang akan 
membentuk corak dasar Islam di Nusantara yang bersifat sufistik. Kedua, Gus Dur mengafirmasi keragaman bentuk keislaman yang dilahirkan oleh keragaman wilayah dan model konversi Islam di ragam wilayah tersebut. Pada titik selanjutnya, keragaman ini yang akan menghadirkan keragaman politik Islam yang lahir dari keragaman geo- kultural keislaman. Ketiga, Gus Dur menempatkan abad ke-13 sebagai poros gelombang islamisasi Nusantara dan memuncak pada pendirian berbagai kerajaan Islam pada abad ke-15M.

Paparan historis Gus Dur berhasil mengonstruksikan corak keislaman di Nusantara yang dibentuk oleh proses kesejarahan yang telah dijelaskan dalam uraian historis di atas. Di titik ini Gus Dur juga menjelaskan:

"Masa abad ke-13, Islam datang di Indonesia sudah dalam bentuk yang dikembangkan di Persia dan kemudian di anak Benua India, yang berorientasi sangat kuat pada tasawuf. Oleh karena itulah kita dapati bahwa tasawuf adalah orientasi yang menentukan corak keilmuan dan tradisi keilmuan pada saat itu. Buku-buku tasawuf yang menggabungkan fiqh dengan amal-amal akhlak merupakan bahan pelajaran utama. Di antaranya adalah Bidayatul Hidayah dari Imam al-Ghazali yang merupakan karya fiqh sufistik paling menonjol selama berabad-abad, bahkan sampai abad ini di pesantren-pesantren.

Dalam perjalanan sejarahnya yang panjang sejak abad ke-13, yaitu selama 7 abad ia berkembang..., manifestasi keilmuan yang seperti ini bertumpang tindih dengan pandangan-pandangan dan perilaku mistik orang Jawa atau penduduk setempat. Demikian juga ia bertumpang tindih dengan perkembangan beberapa aliran tasawuf yang menyimpang dari ortodoksi, seperti faham wahdaniyah atau wahdat alwujud. Hal ini dapat kita jumpai pada Abdurrauf Singkel dan beberapa tokoh lain di masa itu. Perdebatan antara ar-Raniry dengan gurunya yang menghasilkan "pemurnian" ajaran tasawuf di Aceh pada abad ke-16, menunjukkan dengan jelas bahwa manisfestasi fiqh sufistik telah merasuki keseluruhan kehidupan ilmiah orang Islam. Waktu itu yang dipentingkan adalah pendalaman akhlak dalam bentuk pengamalannya secara tuntas dan pendalaman pemahaman sufistik pada kehidupan. Buku utama yang dipakai tentunya Syarh Hikam karya Ibn Atha'illah Asakandary, salah seorang penulis sufi paling terkenal" (Wahid, 2007: 9-10). 
Uraian di atas masih menunjukkan analisa historis Gus Dur atas kehadiran Islam di Nusantara. Hanya saja secara eksplisit, ia menunjuk Persia dan anak benua India, sebagai dua wilayah yang menjadi saringan kultural dari Islam yang hadir di Nusantara. Akibat saringan ini, maka Islam yang hadir merujuk pada Islam sufistik. Meskipun corak sufisme awal cenderung tumpang tindih dengan mistik lokal dan aliran tasawuf heterodoks seperti wahdat al-wujud, namun akhirnya ia tersempurnakan menjadi apa yang Gus Dur sebut sebagai fiqih-sufistik. Yakni penyatuan antara syariat dan tasawuf dalam manifestasinya yang bersifat akhlaqi. Artinya, fiqih-sufistik adalah tasawuf akhlaqi yang membungkus pemahaman sufistik dengan ketaatan fiqhiyyah-syar'iyyah dalam kerangka penyempurnaan akhlaq. Berbeda dengan corak tasawuffalsafi yang berhasrat pada penemuan kesatuan filosofismistik antara hamba dengan Tuhan. Tasawuf akhlaqi lebih tertarik dengan pensucian hati dan perbaikan perilaku yang nampak dalam kehidupan sehari-hari.

Sebagai corak paripurna dari keislaman Nusantara, fiqih sufistik memang merupakan penyampurnaan dari gelombang awal Islam yang merujuk pada gelombang sufisme dan syariah. Yang tersebut terakhir ini merupakan gelombang pendisiplinan syariah atas tasawuf yang telah mengalami pertemuan dengan tradisi mistik lokal. Karena dianggap menyimpang, maka kalangan syariat berupaya mengerem heterodoksi tasawuf ini, baik melalui pelarangan ajaran hingga hukuman atas para penyebar mistik tersebut, seperti pembakaran kitab-kitab wujudiyyah dari Hamzah Fansuri oleh Nuruddin al-Raniri atau penghakiman Walisongo atas Syekh Siti Jenar. Di titik ini tasawuf masih dibenturkan dengan syariat sehingga para ulama lulusan Mekkah seperti di antarnya KH Muhammad Hasyim Asy'ari (Pendiri NU) menyempurnakan tahapan ini dengan pesantren sebagai pusat islamisasi. Dalam hal ini, Gus Dur memaparkan:

"Dengan demikian, terjadilah pengiriman anak-anak muda dari kawasan Nusantara untuk belajar di Timur-Tengah dan akhirnya mereka menghasilkan korps ulama yang tangguh yang mendalami ilmu-ilmu agama di Semenanjung Arabia, terutama di Makkah. Lahirlah ulama- ulama besar seperti Kiai Nawawi Banten, Kiai Mahfudz Tremas, Kiai Abdul Ghani Bima, Kiai Arsyad Banjar, Kiai Abdus Shomad Palembang, Kiai Hasyim As'ari, Kiai Khalil Bangkalan...

Mereka ini membawakan orientasi baru pada manifestasi keilmuan di Vol. 4 No. 1 April $2018 \quad$ Halaman $21-40$ 
lingkungan pesantren, yaitu orientasi pendalaman ilmu fiqh secara tuntas. Perdebatan mengenai hokum agama dilakukan dengan serius, tidak hanya melakukan kajian terhadap kitab fiqh yang besar-besar, melainkan juga dengan mengembangkan alat bantunya, seperti ilmu-ilmu bahasa Arab yang tuntas, ilmu tafsir, ilmu hadist dan tidak lupa juga ilmu akhlak.

...Namun berbeda dengan ulama-ulama di daerah lain, terutama di TimurTengah, para ulama yang menamakan diri sebagai ulama syari'at itu, tetap saja berpegang pada akhlak sufistik yang telah berkembang selama berabad-abad di Indonesia" (Wahid, 2007: 225-227).

Bisa ditarik kesimpulan bahwa Gus Dur menempatkan pesantren dan model keislaman di dalamnya sebagai wujud paripurna dari Islam di Nusantara. Hal ini terjadi karena corak Islam fiqih-sufistik dengan kompleksitas pendalaman keilmuan Islam di dalamnya merupakan gelombang penutup sekaligus penyempurna atas gelombang Islam sebelumnya, yaitu syariatisasi tasawuf. Dikatakan penyempurna, karena ia tidak membuang gelombang awal Islam, melainkan mempertemukannya dalam kesatuan paripurna. Hal ini terlihat pada rekonsiliasi antara tasawuf dan syariah di dalam keislaman model fiqih-sufistik. Di sisi lain, pesantren sebagai subkultur merupakan produk dari pribumisasi Islam melalui apa yang Gus Dur sebut sebagai perwujudan kultural Islam. Dalam hal ini Gus Dur menyatakan:

"Karena hakikat pesantren sebagai titik mula proses transformasi, dengan sendirinya pesantren dipaksa oleh keadaan menjadi alternatif terhadap pola kehidupan yang ada. Peranan sebagai pilihan ideal ini sangatsesuai dengan perwujudan kultural agama Islam yang sampai ke Kepulauan Nusantara.

Sebagaimana dapat disimpulkan dari sejarah penyebaran Islam di kawasan ini, perwujudan cultural Islam adalah perpaduan antara doktrin-doktrin formal Islam dan kultus para wali (yang berpuncak pada kultus wali songo), sebagai sisa pengaruh pemujaan orang-orang suci (hermits) dalam agama Hindu. Perwujudan kultural ini tampak nyata dalam asketisme (az-zuhud) yang mewarnai kehidupan agama Islam di Kepulauan Nusantara, tidak sebagaimana di negeri-negeri Arab sendiri sepanjang sejarahnya" (Wahid, 2007: 12).

Gus Dur menyebut adanya perwujudan kultural Islam, yakni perwujudan Islam yang bersifat kultural. Perwujudan kultural ini dimaknai Gus Dur sebagai perwujudan budaya Islam, hasil pertemuan antara doktrin formal Islam dengan 
pengaruh pemujaan orang-orang suci dari agama Hindu. Pemujaan terhadap orangorang suci ini mungkin merujuk pada tradisi kewalian, yang akhirnya melahirkan konsep dan praksis zuhud (asketisme). Pada titik ini menarik karena Gus Dur menempatkan zuhud sebagai bagian utama dari perwujudan kultural Islam ini. Hal ini menarik karena zuhud merupakan konsep tasawuf, yang jika dianggap mengalami pertemuan dengan tradisi Hindu; ia bisa saja tidak murni tasawuf. Hanya saja, sinyal yang diberikan Gus Dur ini menjadi penting, untuk menetapkan garis pembeda antara Islam Nusantara dengan Islam di Timur-Tengah, karena Gus Dur memang membedakan keduanya.

Dari perwujudan kultural Islam ini, pesantren lahir sebagai bagian dari pelembagaan pada ranah pendidikan berbasis kultural. Pesantren bukan semata lembaga pendidikan, melainkan pelembagaan dari perwujudan kultural Islam. Di dalam pesantren, terdapat dua karakter utama dari Islam Nusantara. Pertama, praktik zuhud yang merupakan nilai utama dari perwujudan kultural Islam. Kedua, pembelajaran khasanah keilmuan Islam yang sangat kaya, yang mencerminkan corak keislaman paripurna yang dibawa oleh para ulama Jawi dari Mekkah. Kedua ciri unik inilah yang membuahkan watak sub-kultur dari pesantren.

Yakni sub dari kultur mainstream yang berbeda, unik, independen, tetapi sekaligus mampu mempengaruhi kultur mainstream tersebut. Dengan demikian, bisa disimpulkan bahwa pesantren merupakan salah satu dari sistem sosial- budaya Islam, sebagai produk paripurna pribumisasi Islam.

Selain merumuskan pola kesejarahan dan corak kultural dari Islam Nusantara, Gus Dur juga melakukan deskripsi atas pola penyebaran Islam di Nusantara. Pola penyebaran ini mengaliri corak geo-kultural yang beragam sehingga melahirkan bentuk-bentuk keislaman yang beragam secara budaya. Keragaman praktik keislaman dalam wujud budaya ini akhirnya membentuk keragaman politik Islam di wilayahwilayah tersebut. Gus Dur menggambarkan:

"Islam came to the Indonesian archipelago in different ways and times. It reached first the northwestern most tip of the region, the shores of Acheh, in the thirteenth century

A.D. The small muslim trading or fishing communities in the area then developed within a century into the kingdoms of Pasai, Perlak and Samudra, which were eventually developed into single strong kingdom of Acheh two 
centuries later. It is not a surprise that such an "orderly" pattern of development from small communities into a single kingdom brought with it also the Islamic nature of the kingdom itself, with religious laws of Islam formed the content of its legal system.

The situation was entirely different in the west coast of Sumatera, the same island where Acheh lies. The Minangkabau matriarchate society of the area had developed its own indigenous customary law, called adat Minang, before Islam reached it from Acheh in the sixteenth century A.D. However, that very society never developed a strong kingdom, so no credible authority could impose a lasting solution in the contention between Islam's religious laws and the existing customary law. The dispute developed into the full scale sixteen-year-long Padri War between two communities led respectively by muslim scholars (ulamas) and local "indigenous" dignitaries, from 1822 to 1838 . Only when the colonial army arrived the war ended, with the Dutch administration imposing a compromise in the form of an adagium: adat bersendi syara' dan syara' bersendi kitabullah (the customary laws should be based on religious ones, and the religious laws should be based on the Holy Qur'an). In fact, certain elements of the customary law are accepted by the religious up to the present, especially in decisions related to inheritance and marriage.

The third type of relationship between Islam and the system of power already existed before that religion reached the archipelago developed into kingdom of Malaka in the Malay peninsula in the fifteenth century

A.D. and the kingdom of Goa in the sixteenth century A.D. In those kingdoms, muslim foreign merchants and traders Islamized the community through marriage with local women, and eventually gained entry into palace hierarchy. Islamic teachings gradually developed into legitimacygiving legal instruments side by side with old pre-Islamic traditions. The palace courts developed into Islamic system of governance with local colors. Sufism was the main integrative elements for both types of tradition.

In the most important area, the most populous island of Java, Islam came into long and sometimes physical conflicts with the pre-Islamic HinduBuddhistic tradition of the Javanese kingdoms. With conquer of the great kingdom of Majapahit at the hands of several muslim princedom in the northcoastal areas of Central Java early in the sisxteenht century A.D., a political compromise was achieved after about ninety years of military conflicts. A new kingdom, Mataram, was established, acknowledging Islam as the religion of the state with the rulers using religious titles such as Executioner of Religious Teachings and God's Caliph in the Land of Java (Kalipatullah ing Tanah Jawi). But, in fact the palace courts were not obliged to observe 
Islamic teachings except for a few formalities. The palace courts were still allowed their pre-Islamic traditions beliefs disguised under the so-called Javanese culture or kejawen" (Wahid, 1980: 20-24).

(Islam datang ke kepulauan Indonesia di dalam cara dan waktu yang berbeda. Ia pertama kali mencapai barat laut wilayah paling ujung, pantai Aceh, pada abad ke-13 M. Komunitas-komunitas perdagangan dan nelayan kecil di area ini kemudian terbentuk di abad itu ke dalam Kerajaan Pasai, Perlak dan Samudra, yang pada akhirnya terbentuk ke dalam kerajaan tunggal yang kuat, Aceh, dua abad kemudian. Tidak mengherankan bahwa suatu pola pembangunan "teratur" dari komunitas kecil kepada kerajaan tunggal membawa pula sifat dasar Islam dari kerajaan itu sendiri, dengan hukum Islam membentuk isi dari sistem legalnya).

Situasi ini sama sekali berbeda di pantai barat Sumatera, pulau yang sama di mana Aceh terletak. Masyarakat matriarkhat Minangkabau di wilayah ini telah membangun hukum adat pribuminya sendiri, disebut adat Minang, sebelum Islam mencapai wilayah itu dari Aceh di abad ke-16 M. Namun, masyarakat tersebut tidak pernah membangun kerajaan kuat, maka tidak ada otoritas kredibel bisa memaksa solusi abadi di dalam kontestasi antara hukum Islam dan hukum adat yang berlaku. Perselisihan terbentuk ke dalam skala besar selama-enam belas-tahun Perang Padri antara dua komunitas yang dipimpin masing-masing oleh sarjana muslim (ulama) dan pejabat pribumi lokal, dari 1822 hingga 1838. Hanya ketika tentara kolonial hadir, perang berhenti, dengan pemerintahan Belanda yang memaksakan kompromi di dalam bentuk adagium: adat bersendi syara dan syara bersendi kitabullah (hukum adat harus didasarkan pada hukum agama, dan hukum agama harus didasarkan pada alQur'an yang suci). Faktanya, elemen-elemen tertentu dari hukum adat diterima oleh hukum agama hingga saat ini, khususnya di dalam keputusan terkait dengan warisan dan pernikahan.

Tipe ketiga hubungan antara Islam dan sistem kekuasaan telah ada sebelum agama tersebut mencapai kepulauan yang terbangun ke dalam kerajaan Malaka di kepulauan Melayu pada abad ke-15 M dan kerajaan Goa pada abad ke-16 M. Di kerajaan-kerajaan tersebut, pedagang muslim asing telah mengislamkan komunitas melalui pernikahan dengan wanita lokal, dan akhirnya bisa masuk ke dalam hirarki istana. Ajaran-ajaran Islam secara perlahan terbangun ke dalam legitimasi-pemberi instrumen legal berdampingan dengan tradisi lama pra-Islam. Pengadilan istana Vol. 4 No. 1 April 2018 Halaman $21-40$ 
terbangun ke dalam sistem pemerintahan Islam dengan warna lokal. Sufisme merupakan elemen integratif utamabagi duatipetradisitersebut.

Di wilayah yang paling penting, pulau yang paling padat, Jawa, Islam telah datang lama dan terkadang mengalami konflik fisik dengan tradisi Hindu-Budha praIslam dari kerajaan Jawa. Bersama penaklukan kerajaan besar Majapahit di tangan beberapa pangeran muslim di wilayah pantai-utara Jawa Tengah awal abad ke-16 M, sebuah kompromi politik telah dicapai setelah sekitar sembilan puluh tahun konflik militer. Sebuah kerajaan baru, Mataram, telah terbangun, mengakui Islam sebagai agama negara dengan penguasa menggunakan gelar keagamaan seperti Penerap Ajaran-ajaran Agama dan Khalifah Tuhan di Tanah Jawa (Kalipatullah ing Tanah Jawi). Tetapi faktanya, pengadilan istana tidak mewajibkan untuk menjalankan ajaranajaran Islam kecuali beberapa formalitas. Pengadilan istana masih membolehkan kepercayaan tradisional pra-Islam yang samar-samar di bawah sebutan budaya Jawa atau kejawen).

Dari uraian teks panjang di atas, terlihat empat pola islamisasi di Nusantara yang menghadirkan hubungan Islam dan kekuasaan yang beragam. Pertama, pola Aceh yang menghadirkan Islam secara kultural dan dengan kultur Islam yang kuat, didirikanlah kerajaan berbasis syariat. Puncak dari kerajaan yang secara total menerapkan syariat ini terjadi pada Kesultanan Iskandar Muda dan Iskandar Tsani. Di dalam kerajaan Aceh tidak ada konstitusi lain selain Islam. Kedua, pola Minangkabau. Karena sebelum kedatangan Islam telah ada hukum adat dan kelompok adat, maka Islam mendapat tantangan. Hal ini yang melahirkan Perang Padri, antara penyebar Islam yang puritan (anti-adat lokal) dan kaum adat. Peperangan ini baru berakhir oleh intervensi Belanda, dan akhirnya melahirkan kesepakatan adat besandi syara, syara besandi kitabullah.

Ketiga, pola Goa. Meskipun sebelum Islam telah ada hukum adat, namun Islam bisa berjalan seiring dengan adat. Keseiringan Islam dan adat ini berlanjut pada ranah konstitusi, yang membuat kerajaan Goa memiliki dua macam konstitusi: Islam dan adat. Keempat, pola Jawa. Di masyarakat Jawa telah ada aliran Kejawen sebelum kehadiran Islam. Maka kerajaan Mataram Islampun mengakomodir Kejawen dengan memberinya ruang bebas secara kultural. Di sisi lain, pola legitimasi raja IslamVol. 4 No. 1 April 2018 Halaman $21-40$ 
Jawapun tetap menggunakan legitimasi Kejawen sebagai basis kekuasaan, di samping legitimasi keislaman. Hal ini terlihat di dalam gelar raja Mataram sebagai Senapati ing Ngalaga Sayyidin Panatagama Khalipatullah ing Tanah Jawi.

Keempat pola islamisasi ini memberikan dampak serius, yang menunjukkan keragaman corak keislaman di masing wilayah. Di Aceh, karena memiliki sejarah kekuasaan Islam yang kuat, telah membangkitkan aspirasi syariah yang kuat. Maka penegakan syariat Islam melalui Peraturan Daerah dan pembentukan suatu Mahkamah Syariat, dipahami sebagai penjagaan identitas kultural Aceh yang telah terjaga oleh kesejarahan Islam di Aceh. Hal ini berbeda dengan Minangkabau yang tetap menyisakan puritanisme Islam, sehingga Islam hingga kini tidak diformalkan pada ranah pemerintahan daerah. Ketiadakan formalisasi Islam ini kemudian ditutupi oleh hubungan Islam dan adat secara kultural melalui prinsip adat bersendi syara, syara bersendi kitabullah. Hal berbeda dengan Goa dan Jawa (pedalaman). Karena mistik lokal telah menjadi bagian dari tradisi lokal, maka kedua wilayah ini mampu menyandingkan Islam dengan mistik lokal di dalam ranah kenegaraan. Tentu menurut perspektif Aceh dan Minangkabau, penyatuan antara Islam dan mistik lokal pastilah dihukumi sebagai sinkretisme, dan bertentangan dengan otentisitas Islam. Dengan demikian, keragaman dari pola keislaman di empat daerah ini akhirnya merepresentasikan keragaman pandangan keislaman di antara umat Islam dan gerakan- gerakan Islam yang saling berbenturan.

\section{PENUTUP}

Dari uraian di atas, bisa diambil kesimpulan bahwa Gus Dur memiliki dua pendekatan di dalam melihat Islam di Nusantara, sebagaimana termaktub di atas. Pendekatan pertama bersifat preskriptif, dengan menggunakan perspeksi tertentu di dalam melihat Islam di Nusantara. Artinya, Gus Dur tidak lagi deskriptif (hanya menggambarkan realitas), karena ia telah memiliki asumsi dasar yang ideal tentang Islam di Nusantara. Dari pendekatan presrikptif ini lahirlah terma Islam Nusantara, yang perlu dibedakan dengan Islam di Nusantara.

Islam Nusantara adalah corak keislaman yang khas Nusantara. Corak ini terbentuk oleh mekanisme islamisasi yang merujuk pada pribumisasi Islam. Kekhasan dalam corak Islam Nusantara ini tentulah corak budaya Nusantara itu sendiri, yang 
bersifat eklektik, menyerap dan asimilatif. Dengan demikian, Islam Nusantara menurut Gus Dur adalah corak keislaman yang terbentuk oleh pribumisasi Islam, sementara pribumisasi Islam merupakan mekanisme islamisasi yang khas di Nusantara. Dengan pendekatan preskriptif ini, Islam Nusantara akhirnya perlu dibedakan dengan "Islam Arab" yang merupakan corak khas Islam di Arab.

Dalam pendekatan preskriptif ini, Gus Dur kemudian menggagas adanya perwujudan kultural Islam yang di dalamnya memuat corak keislaman fiqih-sufistik. Yakni sebuah corak keislaman, hasil dari pertemuan antara gelombang tasawuf dan syariah yang hadir di Nusantara, kisaran abad ke-13 hingga 16

M. Pada titik inipun, Gus Dur sudah bersikap memilih, sebagai bagian dari pendekatan preskriptif. Sikap memilih ini terlihat dari pilihannya atas peran tasawuf di dalam proses pribumisasi Islam, dengan menganulir pandangan sejarah yang melihat para pedagang Arab sebagai pembawa Islam. Pilihan atas tasawuf sebagai corak keislaman yang hadir di Nusantara ini

Akhirnya membentuk bentuk keislaman tertentu yang ia sebut sebagai fiqihsufistik. Tentu fiqih-sufistik ini tidak terdapat di daerah yang nuansa syariahnya terlalu dominatif, dan juga tidak terjadi di daerah yang mistik Islam-Jawanya terlalu hegemonik. Oleh karenanya, ketika Gus Dur menahbiskan fiqih-sufistik sebagai corak ideal Islam Nusantara, yang ia rujuk tentulah corak keislaman pesantren yang menurutnya merupakan produk paripurna Islam Nusantara.

Gus Dur juga tidak murni deskriptif dalam menjelaskan pola historis terbentuknya corak Islam Nusantara, melainkan preskriptif: penggambaran yang dibentuk oleh pra-asumsi yang melekat dalam suatu cara berpikir. Pra-asumsi itu adalah kesesuaian antara tradisi Islam dengan tradisi lokal. Kesesuaian inilah yang akhirnya melahirkan pendekatan pribumisasi Islam, yang membentuk suatu perwujudan kultural Islam. Disebut kultural, karena perwujudan Islam ini tidak bersifat politis dan tidak membutuhkan struktur kekuasaan untuk menubuhkan aturan Islam. Ia hanya butuh kultur, di mana nilai-nilai Islam bisa tersemai melalui adat dan tradisi masyarakat. Salah satu struktur budaya yang mewakili perwujudan kultural Islam itu adalah pesantren yang memuat corak keislaman fiqih-sufistik. Sebuah corak Islam, yang merupakan produk kimiawi antara tasawuf dan syariah yang terjadi Vol. 4 No. 1 April 2018 Halaman $21-40$ 
selama gelombang islamisasi Nusantara sejak abad ke-13 M.

Pendekatan kedua, deskriptif. Dalam pendekatan ini, Gus Dur tidak hendak mengemukakan suatu corak Islam Nusantara, melainkan sebatas menggambarkan Islam di Nusantara. Dalam deskripsinya, Islam di Nusantara tersebar di berbagai wilayah geo-kultural yang beragam dan akhirnya membentuk pola islamisasi dan corak keislaman yang beragam. Islam di Aceh bisa menjadi konstitusi negara karena sejak awal Islam berkembang dari komunitas kultural hingga menjadi institusi kekuasaan. Hal ini yang berbeda dengan Minangkabau yang tidak memungkinkan hegemoni Islam sebab sejak awal terdapat hukum adat Minang yang mengakar di masyarakat. Di wilayah Goa dan Jawa situasinya hampir serupa, di mana tradisi mistik bertemu dengan tasawuf, sehingga Islam dan mistik lokal bisa berdampingan di dalam struktur kekuasaan. Tentu Jawa yang dimaksud Gus Dur adalah Jawa pedalaman, bukan Jawa pesisir. Sebab Jawa pesirir telah melahirkan corak keislaman sufistik yang memusat tidak di dalam kerajaan, melainkan pesantren. Melalui pendekatan deskriptif ini, Gus Dur ingin menandaskan keragaman Islam sehingga upaya menciptakan homogenisasi kultur Islam yang dilakukan oleh kaum fundamentalis, tentu bertentangan dengan realitas keislaman itu sendiri.

Dalam kaitan pola kesejarahan pembentuk corak Islam Nusantara, Gus Dur kurang mengeksplorasi pola-pola politik Islam di dalam kerajaan Islam. Ia hanya menggambarkan secara singkat empat pola politik Islam di Kerajaan Aceh, Minangkabau, Goa, dan Mataram. Sayangnya Gus Dur tidak mengeksplorasi pola politik Islam di Kerajaan Demak misalnya, yang merupakan kerajaan Islam pertama di Jawa. Dengan demikian, Gus Dur kurang dalam menjelaskan secara eksplisit terkait perwujudan politik Islam, hasil dari strategi struktural Walisongo karena Dewan Wali ini merupakan para founding fathers kerajan-kerajaan Islam, seperti Kerajaan Demak, Kesultanan Cirebon, dan Mataram Islam. Kekurangan ini bisa dipahami dalam konteks pribumisasi Islam itu sendiri yang menjadi strategi mainstream para Wali.

Jadi, meskipun Walisongo juga menggunakan strategi politik dengan membidani kerajaan-kerajaan Islam. Namun pendekatan utama dalam dakwah merujuk pada pribumisasi Islam pada ranah kultural (budaya). Karena melalui Vol. 4 No. 1 April 2018 Halaman $21-40$ 
budaya, Islam bisa didakwahkan secara damai melalui pembentukan kontinuitas budaya sehingga meskipun terjadi pergantian agama dari Hindu-Buddha ke Islam; budaya Nusantara tetap terjaga. Artinya, transformasi kebudayaan yang digerakkan oleh Islam hanya mengubah esensi normatif tidak tidak menghilangkan substansi budaya yang menjadi titik tekan corak Islam Nusantara. Sebab itu, transformasi budaya Islam di Nusantara telah menjaga kesinambungan budaya Nusantara itu sendiri.

\section{REFERENSI}

Abdurrahman Wahid, Salahkah Jika Dipribumikan?, dalam Tuhan Tidak Perlu Dibela, (Yogyakarta: LKiS, 1999).

Abdurrahman Wahid, Pribumisasi Islam dalam Pergulatan Negara, Agama, dan Kebudayaan, (Depok: Desantara, 2001).

Wahid, Pesantren sebagai Subkultur, dalam Menggerakkan Tradisi, Esai-esai Pesantren, (Yogyakarta: LKiS, 2007).

Abdurrahman Wahid, Islam in Indonesia: Challenge and Future Prospects, sumber tak terlacak, 14 Maret 1985.

Abdurrahman Wahid, The Dynamic of Islamic Movements in Southeast Asia and Their Impacts on the Region's Resilience, the 5th Seminar on Religion as a Field of Research and Study, Jakarta, 26-28 Februari 1981.

Abdurrahman Wahid, Islam and Pancasila: Development of A Religious Political Doctrine in Indonesia, makalah Dialogue Group \#9: Religious Beliefs: The Transmission and Development Doctrine, di Seoul, 25 Agustus 1990.

Abdurrahman Wahid, Islam: The State and Development in Indonesia, Jakarta: LIPI, 1980. 